\title{
Syndromic orbital border hypoplasia
}

INSERM

\section{Source}

INSERM. (1999). Orphanet: an online rare disease and orphan drug data base. Syndromic orbital border hypoplasia. ORPHA:98606

Syndromic orbital border hypoplasia is a rare disorder observed in two families to date and characterized by agenesis of the orbital margin, varying defects of the lacrimal passages, hypoplasia of the palpebral skin and tarsal plates and atresia of the nasolacrimal duct. 